\title{
The Effect Of Accrual Reliability On Audit Pricing
}

Jong Eun Lee, Ph.D., Sungkyunkwan University, South Korea Cheol Lee, Ph.D., Wayne State University, USA

\begin{abstract}
This study investigates how accrual reliability is associated with audit fees. Since the enactment of the Sarbanes-Oxley Act of 2002, financial reporting has shifted toward a more principles-based accounting paradigm, along with an emphasis on fair value accounting by standard setters. As a result, auditors are exposed to more subjective accrual estimation processes, including accounting estimates. In the current financial reporting environment, external auditors are required to pay greater attention to accrual components that are largely based on accounting estimates to evaluate the reasonableness of accrual measurements. In this study, we find a negative association between the level of accrual reliability and audit fees. That is, the greater the potential litigation risk (due to accrual components based on more subjective or less reliable estimation processes), the more the audit work, and the higher the fees paid to external auditors.
\end{abstract}

Keywords: Accounting Estimates; Audit Pricing; Accrual Reliability

\section{INTRODUCTION AND HYPOTHESIS DEVELOPMENT}

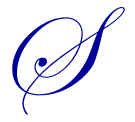

ince the enactment of the Sarbanes-Oxley Act (hereafter SOX) of 2002, financial reporting has shifted to a more principles-based accounting paradigm with an emphasis on fair value accounting and accounting estimates. ${ }^{1}$ For example, the Financial Accounting Standard Board (hereafter FASB) has issued several standards related to accounting estimates, such as Statement No. 149 (2003), Amendment of Statement 133 on Derivative Instruments and Hedging Activities, Statement No. 132 (2003 revision), Employers' Disclosures about Pensions and Other Postretirement Benefits - an amendment of FASB Statements No. 87, 88, and 106, Statement No. 151 (2004), Inventory Costs - an amendment of ARB No. 43, Chapter 4, and Statement No. 123 (2004 revision), Share-based Payment. As a result, external auditors are exposed to more subjective accrual measurements, including accounting estimates, to determine the fairness of clients' financial statements. In other words, currently, balance sheets contain more subjective and complex estimation-based accounts such as goodwill, impaired longlived assets, in-process R\&D, and pension and retirement liabilities and expenses.

While accruals are fundamentally measured on an estimation basis, the reliability levels of the accrual estimation process vary widely among accrual components. Notably, the subjectivity in the estimation process directly affects the reliability of the accrual components. In this study, we posit that the subjectivity is negatively associated with accrual reliability. For example, it is easier to calculate accrued salaries or prepaid expense than pension and retirement liabilities and expenses, which are determined by a model with relatively more subjective factors. In the measurement process, managements could use subjective or discretionary accounts for opportunistic purposes to manipulate the firm's performance or financial position. Thus, in relation to financial statement audit, external auditors need to pay more attention to these accounts with a higher degree of professional judgment. Furthermore, the increase in accruals with more subjective and complex estimation processes can expose external auditors to a more litigious financial-reporting environment and/or lead to additional audit work to evaluate the reasonableness of accrual measurements.

\footnotetext{
${ }^{1}$ The definition of the principles-based accounting system in Section 108(d) of the Sarbanes-Oxley Act of 2002 is based on a report of the Security and Exchange Commission (SEC, 2003), in which the principles-based accounting system was defined as objective-oriented accounting.
}

(C) 2013 The Clute Institute http://www.cluteinstitute.com/ 
In this study, we examine how the level of accrual reliability is associated with audit pricing. The audit risk literature (e.g., Simunic, 1980; Pratt and Stice, 1994; Simunic and Stein, 1996; Seetharaman et al., 2002) suggests that audit fees are determined by the combined effect of business risk and audit effort. For example, the uncertainty and bias involved in evaluating accounting estimates embedded in the accrual components may decrease the reliability of accruals, subsequently causing potential litigation risk and/or more audit work.

Regarding the association between risk and audit fees, prior studies (e.g., O'Keefe et al., 1994; Pratt and Stice, 1994; Morgan and Stocken, 1998; Johnstone, 2000; Bell et al., 2001; Seetharaman et al., 2002) report that clients with high business risk pay higher audit fees. Other studies (Palmrose, 1986; Simunic, 1980; Simunic and Stein, 1996) document that audit fees rise as auditor litigation exposure increases. Because a high level of accrual subjectivity or a low level of reliability is more likely to increase litigation exposure due to the inherent subjectivity in accounting estimates, we argue that a level of accrual reliability is also likely to be an economic determinant of audit fees.

At the same time, increasing subjectivity in accrual estimation in the course of financial reporting may lead to additional work by auditors to assure the reasonableness of the subjective and complex accrual estimation process. In fact, a body of audit-pricing literature (e.g., Simunic, 1980; Simunic and Stein, 1996; Seetharaman et al., 2002; Schelleman and Knechel, 2010) suggests that the audit fee is a function of audit efforts. Thus, we postulate that, in the face of more estimation-based accruals, auditors may have to undertake additional audit work to assure the reasonableness of the measurement process of the reported accounting estimates.

Taken together, we predict that firms with more accruals based on subjective estimation processes are more likely to pay high audit fees. Therefore, we hypothesize that

H: The level of reliability of accrual measurements is negatively associated with audit fees.

While relevant prior study provides evidence that total accruals are positively associated with audit pricing, we argue in this study that each component of total accruals has a differential impact on auditor compensation, assuming that accrual components based on more subjective estimation processes produce less reliable accrual quality.

In the following section, we describe the research design and sample used in the study. Results are detailed in Section III. In the last section, we provide discussions.

\section{RESEARCH DESIGN AND SAMPLE}

Following the study of Richardson et al. (2005), we decompose total accruals into seven components: (1) change in current assets, (2) change in current liabilities, (3) change in non-current assets, (4) change in non-current liabilities, (5) change in short-term investment, (6) change in long-term investment, and (7) change in financial liabilities. According to Richardson et al. (2005), each accrual component has a different level of reliability due to a different magnitude of accounting estimates embedded in it. They suggest that the following accrual components are less reliable: change in current assets, change in non-current assets, change in non-current liabilities, and change in long-term investment. In other words, their accrual quality is lower than that of the other accrual components. For example, current assets involve more subjective (i.e., less reliable) accrual measurements of allowance for doubtful accounts and inventory cost flow assumptions, which are respectively related to receivables and inventory. Noncurrent assets require the estimation of write-downs and amortization, related to property, plant and equipment, and intangible assets.

As per the above discussion, we create the variable $\Delta$ LessReliable_EST, which combines four accrual components: change in current assets $(\triangle C O A)$, change in non-current assets $(\triangle N C O A)$, change in non-current liabilities $(\triangle N C O L)$, and change in long-term investment $(\triangle L T I)$. The variable $\Delta$ LessReliable_EST includes accrual components based on more subjective (i.e., less reliable) estimation processes.

To test the hypothesis, we use the following regression model. $L O G A F_{i t}=\alpha_{0}+\alpha_{1} \mid \Delta$ LessReliable_EST $i t+\alpha_{2}\left|\Delta C O L_{i t}\right|+\alpha_{3}\left|\Delta S T I_{i t}\right|+\alpha_{4}\left|\Delta F I N L_{i t}\right|+\alpha_{5} C_{T R} L_{i t}+\varepsilon_{i t}$ 
where $L O G A F$ is a natural logarithm of audit fees and $\mid \triangle$ LessReliable_EST $\mid$ is the sum of the following variables: $|\triangle C O A|$ (absolute value of change in current assets), $|\triangle N C O A|$ (absolute value of change in non-current assets), $|\triangle N C O L|$ (absolute value of change in non-current liabilities), and $|\triangle L T I|$ (absolute value of change in long-term investment). $|\triangle C O L|$ is the absolute value of change in current liabilities, $|\triangle S T I|$ the absolute value of change in short-term investment, and $|\triangle F I N L|$ the absolute value of change in financial liabilities. CTRL is a group of control variables: profitability $(R O A)$, measured as operating income after depreciation (OIADP in Compustat data) deflated by average total assets, leverage ( $L E V)$, measured as long-term debt (DLTT in Compustat data) deflated by average total assets, capital intensity (CAP), measured as depreciation expense (DPC in Compustat data) deflated by sales (SALE in Compustat data), total assets (LOGTA), loss (LOSS), industry-dummy variables (two-digit SIC code), and a time-dummy variable.

We postulate that the variable $\mid \Delta$ LessReliable_EST $\mid$, which is based on subjective estimation processes (and therefore has relatively lower accrual reliability), has a positive coefficient in the empirical regression model above.

We obtained financial data from the Compustat Fundamental Annual file and data on external auditors and audit fees from Audit Analytics. We collected data for the sample period 2003 to 2004. From the initial sample, we excluded observations in regulated industries, such as the utilities industry (SIC codes 4900 through 4999) and the financial industry (SIC codes 6000 through 6999). We also excluded observations for which financial data, external auditors' data, or audit fees data were incomplete. The final sample consisted of 8,216 firm-year observations.

\section{EMPIRICAL RESULTS}

\section{Descriptive Analysis}

Table 1 shows descriptive statistics of key variables. The mean (median) of the variable $I \Delta$ LessReliable_EST $\mid$ is $0.241(0.139)$. The means (medians) of the variables $|\triangle C O L|,|\triangle S T I|$, and $|\triangle F I N L|$ are 0.104 , 0.041 , and $0.126(0.034,0.000$, and 0.032$)$, respectively, implying that each distribution is positively skewed. Meanwhile, the variable ROA (mean: -0.174 , median: 0.045 ) is negatively skewed. The mean (median) of LOGTA is 4.998 (4.981).

Table 1

Descriptive Statistics of Key Variables

\begin{tabular}{lccccccc}
\hline \multicolumn{1}{c}{ Variable } & Mean & Median & Std. Dev & $\mathbf{5 \%}$ & $\mathbf{2 5 \%}$ & $\mathbf{7 5 \%}$ & $\mathbf{9 5 \%}$ \\
\hline $\mid \Delta$ LessReliable_EST & 0.241 & 0.139 & 0.299 & 0.028 & 0.074 & 0.274 & 0.842 \\
$\mid \triangle$ COL $\mid$ & 0.104 & 0.034 & 0.319 & 0.002 & 0.013 & 0.074 & 0.357 \\
$|\Delta S T I|$ & 0.041 & 0.000 & 0.109 & 0.000 & 0.000 & 0.026 & 0.236 \\
$|\triangle F I N L|$ & 0.126 & 0.032 & 0.335 & 0.000 & 0.004 & 0.100 & 0.515 \\
ROA & -0.174 & 0.045 & 0.988 & -1.019 & -0.086 & 0.110 & 0.224 \\
LOGAF & 0.469 & 0.260 & 0.549 & 0.033 & 0.110 & 0.616 & 1.640 \\
LOGTA & 4.998 & 4.981 & 2.431 & 0.985 & 3.204 & 6.667 & 9.229 \\
\hline
\end{tabular}

Note: IDLessReliable_EST $\mid$ is the sum of the following variables: $|\triangle C O A|$, the absolute value of change in current assets $(=$ current assets [ACT in Compustat data] - cash and short-term investments [CHE in Compustat data]), $|\triangle N C O A|$, the absolute value of change in non-current assets ( $=$ total assets [AT in Compustat data] - current assets [ACT in Compustat data] investments and advances [IVAO in Compustat data]), $|\triangle N C O L|$ the absolute value of change in non-current liabilities (= total liabilities [LT in Compustat data] - current liabilities [LCT in Compustat data] - long-term debt [DLTT in Compustat data]), $|\triangle L T I|$, the absolute value of change in long-term investment (IVAO in Compustat data). $|\triangle C O L|$, the absolute value of change in current liabilities (= current liabilities [LCT in Compustat data] - debt in current liabilities [DLC in Compustat data]), I $\triangle S T I I$, the absolute value of change in short-term investments (IVST in Compustat data), and $|\triangle F I N L|$, the absolute value of change in financial liabilities(= long-term debt [DLTT in Compustat data] + debt in current liabilities [DLC in Compustat data] + preferred stock [PSTK in Compustat data]). LOGAF is the natural logarithm of audit fees, and LOGTA stands for the natural logarithm of total assets.

Table 2 reports the correlation among the key variables. Auditor compensation (LOGAF) and client size $($ LOGTA) are positively and significantly correlated with each other (correlation $=.765, \mathrm{p}<.0001$ ). The correlation between $|\triangle C O L|$ and $|\triangle F I N L|$ is $0.915(\mathrm{p}<.0001){ }^{2}$ The other correlations are below 0.6.

\footnotetext{
${ }^{2}$ We reran the empirical regression in this study, dropping each variable in turn; however, the results remained the same. (C) 2013 The Clute Institute http://www.cluteinstitute.com/
} 
Table 2

Correlation Coefficients of Key Variables

\begin{tabular}{|c|c|c|c|c|c|c|}
\hline Variable & $\mid \Delta$ LessReliable_EST | & $|\triangle C O L|$ & $|\Delta S T I|$ & $|\triangle F I N L|$ & LOGAF & LOGTA \\
\hline \multirow{2}{*}{$\mid \Delta$ LessReliable_EST $\mid$} & & 0.228 & -0.008 & 0.270 & 0.130 & 0.145 \\
\hline & & $<.0001$ & 0.466 & $<.0001$ & $<.0001$ & $<.0001$ \\
\hline \multirow{2}{*}{$|\triangle C O L|$} & 0.521 & & 0.031 & 0.915 & 0.113 & 0.490 \\
\hline & $<.0001$ & & 0.005 & $<.0001$ & $<.0001$ & $<.0001$ \\
\hline \multirow{2}{*}{$|\triangle S T I|$} & -0.013 & -0.025 & & 0.028 & -0.036 & -0.050 \\
\hline & 0.255 & 0.024 & & 0.011 & 0.001 & $<.0001$ \\
\hline \multirow{2}{*}{$|\triangle F I N L|$} & 0.453 & 0.637 & -0.093 & & 0.293 & 0.507 \\
\hline & $<.0001$ & $<.0001$ & $<.0001$ & & $<.0001$ & $<.0001$ \\
\hline \multirow{2}{*}{$L O G A F$} & 0.290 & 0.525 & 0.026 & 0.544 & & 0.765 \\
\hline & $<.0001$ & $<.0001$ & 0.019 & $<.0001$ & & $<.0001$ \\
\hline \multirow{2}{*}{ LOGTA } & 0.306 & 0.552 & 0.029 & 0.591 & 0.862 & \\
\hline & $<.0001$ & $<.0001$ & 0.007 & $<.0001$ & $<.0001$ & \\
\hline
\end{tabular}

Note: See Table 1 for the definitions of variables. The upper number in each cell is the Pearson correlation coefficient, and the lower number the Spearman rank correlation coefficient.

\section{Multivariate Analysis}

The empirical regression results are shown in Table 3. The dependent variable is the natural logarithm of audit fees. The coefficient (0.034) of the variable $\mid \Delta$ LessReliable_EST $\mid$ is positive and significant (t-statistic $=3.63$ ) at the $1 \%$ level, supporting the argument that the estimation subjectivity embedded in the less reliable accrual components of $\mid \Delta$ LessReliable_EST | increases audit risk and/or audit efforts. However, the other accrual components (i.e., $|\triangle C O L|,|\triangle S T I|$, and $|\triangle F I N L|$ ), which are relatively more reliable, are negatively correlated with audit fees. These findings are interesting, because prior relevant research documents a positive association between total accruals and audit fees, suggesting that total accruals represent information risk (i.e., noise). When decomposing total accruals into several components based on accrual reliability, we find that, while less reliable accrual components increase audit fees, relatively more reliable accrual components decrease audit fees, indicating that two total-accrual forces acting in opposite directions determine audit fees. Moreover, as shown in Table 3, the coefficient (0.215) of LOGTA is positive and significant at the 1\% level, suggesting that client size is one of the most important factors in determining audit fees.

Table 3

Audit Fees Regression

\begin{tabular}{|c|c|c|c|}
\hline \multirow{2}{*}{ Variable $^{a}$} & \multirow{2}{*}{$\begin{array}{c}\text { Expected } \\
\text { sign }\end{array}$} & \multicolumn{2}{|c|}{ Dependent Variable: LOGAF } \\
\hline & & Coefficient & t-statistic $^{b}$ \\
\hline Intercept & $?$ & $-0.829 * * *$ & -43.23 \\
\hline $\mid \Delta$ LessReliable_EST $\mid$ & + & $0.034 * * *$ & 3.63 \\
\hline$|\triangle C O L|$ & + & -0.017 & -2.95 \\
\hline$|\Delta S T I|$ & + & -0.063 & -2.08 \\
\hline$|\triangle F I N L|$ & + & -0.064 & -8.28 \\
\hline$R O A$ & - & $-0.062 * * *$ & -16.69 \\
\hline$C A P$ & + & -0.006 & -1.08 \\
\hline$L E V$ & $?$ & $0.018 * * *$ & 9.98 \\
\hline LOSS & $?$ & $0.069 * * *$ & 8.74 \\
\hline LOGTA & + & $0.215 * * *$ & 67.87 \\
\hline$I N D$ & $?$ & & \\
\hline$Y E A R$ & $?$ & & \\
\hline Adjusted $\mathrm{R}^{2}$ & & & \\
\hline No. of obs. & & & \\
\hline
\end{tabular}

Note: See Table 1 for the definitions of variables.

${ }^{\text {a }} R O A$ (profitability) = operating income after depreciation (OIADP in Compustat data) deflated by average total assets; $C A P$ (capital intensity) = depreciation expense (DPC in Compustat data) deflated by sales (SALE in Compustat data); $L E V$ (leverage) = long-term debt (DLTT in Compustat data) deflated by average total assets; $L O S S=$ loss dummy variable; $L O G T A=$ natural logarithm of total assets; IND = industry-dummy variables (two-digit SIC code); YEAR = time dummy variable.

${ }^{\mathrm{b}}$ The reported t-statistics in the ordinary least squares (OLS) regression are adjusted by using a heteroskedasticity-consistent standard error (White, 1980)

$*, * *$, and, *** indicate statistical significance at the $10 \%, 5 \%$, and $1 \%$ levels (two-tailed), respectively. 


\section{CONCLUSION}

While accruals are in principle estimation based, some accruals (goodwill, impaired long-lived assets, inprocess $R \& D$ ) are more subjective in the estimation process. The recent shift to a principles-based accounting paradigm by standard-setters has exposed external auditors to more subjective and complex accrual estimation processes. In this study, we investigate how the level of reliability of each accrual component in total accruals affects audit fees. We find that accrual components based on more subjective estimation processes (i.e., less reliable accrual components) lead to more audit fees. In other words, the higher the business risk (or the greater the audit work due to the subjectivity in the estimation process), the higher the audit fees. This finding - which has not been considered in related prior literature - is important to policy makers and accounting and auditing professionals in that two forces acting in opposite directions (i.e., more vs. less reliable accrual components) determine audit fees.

\section{AUTHOR INFORMATION}

Jong Eun Lee, Ph.D., Department of Accounting, School of Business, Sungkyunkwan University, South Korea. E-mail: jelee2012@skku.edu (Corresponding author)

Cheol Lee, Ph.D., Department of Accounting, School of Business, Wayne State University, USA. E-mail: cheol@wayne.edu

\section{Data Availability}

The data are publicly available from the sources identified in the paper.

\section{REFERENCES}

1. Bell, T., W. Landsman, and D. Shackelford, 2001. Auditors' perceived business risk and audit fees: Analysis and evidence. Journal of Accounting Research, 39, 35-43.

2. Johnstone, K., 2000. Client acceptance decisions: simultaneous effects of client business risk, audit risk, auditor business risk and risk adaptation. Auditing: A Journal of Practice \& Theory, 19, 1-25.

3. O'Keefe, T., R. King, and K. Glover, 1994. Audit fees, industry specialization, and compliance with GAAS reporting standards. Auditing: A Journal of Practical \& Theory, 13, 41-55.

4. Palmrose, Z., 1986. The effect of nonaudit services on the pricing of audit services: Further evidence. Journal of Accounting Research, 24, 405-411.

5. Pratt, J., and J. D. Stice, 1994. The effects of client characteristics on auditor litigation risk judgments, required audit evidence and recommended audit fees. The Accounting Review, 69, 639-656.

6. Richardson, S., R. Sloan, M. Soliman, and I. Tuna, 2005. Accrual reliability, earnings persistence and stock prices. Journal of Accounting and Economics, 39, 437-485.

7. Schelleman, C., and W. R. Knechel, 2010. Short-term accruals and the pricing and production of audit services. Auditing: A Journal of Practice \& Theory, 29, 221-250.

8. Securities and Exchange Commission, 2003. Study Pursuant to Section 108(d) of the Sarbanes-Oxley Act of 2002 on the Adoption by the United States Financial Reporting System of a Principles-Based Accounting System. Submitted to Committee on Banking, Housing, and Urban Affairs of the U.S. Senate and Committee on Financial Service of the U.S. House of Representativeness. Washington, D. C.: Government Printing Office.

9. Seetharaman, A., F.A. Gul, and S.G. Lynn, 2002. Litigation risk and audit fees: Evidence from U.K. firms cross-listed on U.S. markets. Journal of Accounting \& Economics, 33, 91-115.

10. Simunic, D.A., 1980. The pricing of audit services: theory and evidence. Journal of Accounting Research, $18,161-190$.

11. Simunic, D.A., and M.T. Stein, 1996. The impact of litigation risk on audit pricing: a review of the economics and the evidence. Auditing: A Journal of Practice and Theory, 15, 119-134.

12. St. Pierre, K. and J. Andersson, 1984. An analysis of the factors associated with lawsuits against public accountants. Accounting Review, 59, 242-263.

13. White, H., 1980. A heteroskedasticity-consistent covariance matrix estimator and a direct test for heteroskedasticity. Econometrica, 48, 817-838. 
NOTES 